\title{
From leadership to biodiversity: the good of small things
}

\author{
Kamran Abbasi executive editor
}

The BMJ

Small things matter. The biologist E O Wilson was first a world expert in myrmecology, the study of ants, before his appreciation of our planet's evolutionary progress and what the future might hold turned him into the "father of biodiversity." In The God of Small Things by Arundhati Roy we learn the importance of focusing on the smaller matters of the here and now when our bigger ambitions seem too distant to touch.

You might argue that we shouldn't sweat the small stuff, as the psychotherapist Richard Carlson put it, but can a leader, whether in biodiversity, environmental activism, or healthcare, afford to keep their eyes fixed on the big picture and leave the details to others? If you believe in the value of clinical leadership you will know that the small stuff matters and recognise the virtue of marginal gains. Clinicians bring an understanding of the fundamental transactions in patient care to their leadership roles. Indeed, David Oliver reminds us that meaningful improvement is driven at the local level by small and medium sized teams (doi:10.1136/bmj.14339). The role of the wider organisation is to create the right culture, incentives, and investments in education and data.

Despite the highest endorsements, only $10 \%$ of NHS chief executives are clinically trained. A major barrier to increasing those numbers is trading the job security of a clinician for the less secure position of chief executive, finds Jacqui Thornton (doi:10.1136/bmj.14341). She quotes NHS Providers' Saffron Cordery: "We've got to stop sacrificing the leaders." But how is that possible in our culture of corporate blame, where the buck stops with the chief executive? The answer might be to borrow from evolutionary biology and diversify, to create new roles for clinicians adapted to today's threats to healthcare's culture and environment.
Threats are important. You will see them in the definition of post-traumatic disorder, where diagnosis can be based on the patient's exposure to actual or "threatened" death, serious injury, or sexual violence (doi:10.1136/bmj.12372). You might add to your personal threats by taking dual antiplatelet therapy for too long (doi:10.1136/bmj.12222), defying your endogenous circadian system (doi:10.1136/bmj.12327), or resisting physical activity from middle age onwards (doi:10.1136/bmj.12323). In particular, this week we help you lessen the threats faced by your patients with acute kidney injury (doi:10.1136/bmj.14007).

The worst threats, however, are those that we humans pose to our planet and to all creatures great and small (doi:10.1136/bmj. 12385). A landmark UN report finds that our species has significantly altered $75 \%$ of land and $66 \%$ of ocean areas. ${ }^{1}$ By destroying our planet's biodiversity we are killing off the opportunity to learn from and harness the secrets of survival that exist in fungi and bacteria, in amphibians and sharks. E O Wilson argues that half the Earth's land surface must be secured for wildlife. On a smaller, more local level we offer examples from around the world of how to transform healthcare for the sake of the environment (doi:10.1136/bmj.12398).

All of us have a leadership role to play. When it comes to biodiversity and the planet, do sweat the small stuff.

1 United Nations. Nature's dangerous decline "unprecedented"; species extinction rates "accelerating." May 2019. https://www.un.org/sustainabledevelopment/blog/2019/05/ nature-decline-unprecedented-report.

Published by the BMJ Publishing Group Limited. For permission to use (where not already granted under a licence) please go to http://group.bmj.com/group/rights-licensing/ permissions 